Original Research Paper

\title{
Pelatihan Pembuatan Bak Terpal Untuk Usaha Budidaya Perikanan di Desa Talabiu Kabupaten Bima
}

\author{
Alis Mukhlis ${ }^{1 *}$, Sanca Rahmatullah ${ }^{1}$, Septiana Dwiyanti ${ }^{1}$, Anita Prihatini Ilyas ${ }^{1}$, Awan \\ Dermawan $^{1}$
}

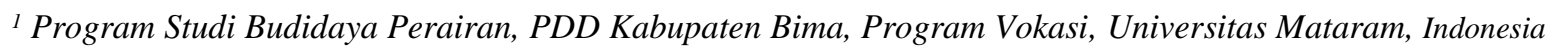

https://doi.org/10.29303/jpmpi.v3i2.1195

Sitasi: Mukhlis, A., Rahmatullah, S., Dwiyanti, S., Ilyas, A. P \& Dermawan, A. (2021). Pelatihan Pembuatan Bak Terpal Untuk Usaha Budidaya Perikanan di Desa Talabiu Kabupaten Bima. Jurnal Pengabdian Magister Pendidikan IPA 4(4)

\author{
Article history \\ Received:15 November 2021 \\ Revised: 05 Desember 2021 \\ Accepted: 10 Desember 2021 \\ *Corresponding Author: Alis \\ Mukhlis, Universitas Veteran \\ Bangun Nusantara, Sukoharjo, \\ Indonesia \\ Email: \\ alismukhlis@unram.ac.id
}

\begin{abstract}
Kesuksesan produksi perikanan budidaya sangat terkait dengan penyediaan fasilitas pendukung seperti bak tempat perawatan, pemeliharaan dan pembesaran komoditi perikanan. Bak terpal merupakan salah satu wadah budidaya komoditi perikanan yang kini kian populer di masyarakat disebabkan oleh beberapa alasan diantaranya yaitu biaya pembuatan lebih murah, pembuatan lebih cepat, mudah dirawat dan dipindahkan serta dapat dibangun pada lahan yang lahan terbatas. Potensi Desa Talabiu yang berlokasi di Kecamatan Woha Kabupaten Bima sebagai sentra produksi komoditi perikanan payau menjadi alasan perlunya dilakukan pembinaan masyarakat perikanan melalui kegiatan pelatihan pembuatan wadah budidaya yaitu bak terpal dengan tujuan untuk meningkatkan keterampilan masyarakat sasaran dalam pembuatan bak terpal sebagai wadah budidaya ikan. Kegiatan ini diharapkan dapat merangsang munculnya usaha budidaya ikan secara mandiri yang berkelanjutan. Kegiatan pelatihan telah dilakukan pada tanggal 4 November 2021 berlokasi di Desa Talabiu Kecamatan Woha Kabupaten Bima. Kegiatan ini dilaksanakan dengan manjalin kemitraan bersama dengan Koperasi "Sama Ngawa Karawi". Kegiatan ini dihadiri oleh peserta sebanyak 36 orang berasal dari anggota koperasi, masyarakat pembudidaya ikan, tokoh masyarakat sekitar, dan mahsiswa Program Studi Budidaya Perairan Program Diploma Tiga Program Vokasi Universitas Mataram yang kampusnya berlokasi di Kabupaten Bima. Peserta yang hadir telah menunjukkan respon yang sangat positif dan sangat mengharapkan bahwa kemitraan yang telah berlangsung dapat dilanjutkan hingga ke tahap-tahap berikutnya seperti pendampingan pada tahap budidaya, persiapan pakan yang murah dan efektif, pasca panen serta pemasaran. Keterlibatan Program Diploma Tiga Program Studi Budidaya Perairan Vokasi Bima Universitas Mataram di Kabupaten Bima yang berkelanjutan dalam kegiatan ini sangat dibutuhkan
\end{abstract}

Keywords: Bima, bak terpal, pelatihan, talabiu.

Fasilitas utama dan media yang dibutuhkan dalam kegiatan budidaya perikanan meliputi wadah atau bak pemeliharaan, air sebagai media pemeliharaan dan peralatan pensuplai oksigen. Ketiga komponen ini memiliki peranan yang sangat penting dan mempengaruhi kelangsungan proses budidaya perikanan. Bak pemeliharaan ikan menempati 
urutan tertinggi dalam biaya investasi suatu unit budidaya dan menjadi faktor pembatas ada atau tidaknya kegiatan budidaya perikanan di masyarakat.

Berbagai macam wadah dapat digunakan untuk usaha budidaya komoditi perikanan. Wadah yang digunakan memiliki berbagai macam bentuk, ukuran, jenis bahan, dan daya tampung airnya yang ditentukan berdasarkan ketersediaan modal, kondisi lingkungan, jenis spesies dan kapasitas produksi yang ditargetkan oleh si pembudidaya ikan. Salah satu jenis bak yang dapat digunakan untuk budidaya ikan maupun udang adalah bak terpal. Jenis bak ini kini kian populer di masyarakat. Terutama bagi kalangan pembudidaya yang memiliki modal dan lahan terbatas. Biaya yang dibutuhkan untuk membuat bak terpal cukup murah dibandingkan bak semen dan memiliki umur ekonomis yang lebih panjang, paling tidak 4 hingga 6 kali masa budidaya dibandingkan kolam tanah biasa (Lisanty et al., 2020).

Berbagai laporan menunjukkan keberhasilan produksi ikan dengan menggunakan bak terpal baik untuk budidaya ikan Lele (Su'udi dan Wathon, 2018), Nila (Sari et al., 2017; Sukardi et al., 2018), Patin (Ayuzar \& Zuriani, 2017), Bandeng (Rundupadang, 2020) dan juga udang Vanname (Mas'ud \& Wahyudi, 2018; Irsyam et al., 2019). Selain lebih praktis, bak terpal mudah diaplikasikan di lahan terbatas serta biaya pembuatan yang relatif lebih murah dibanding bak beton. Keunggulan lainnya adalah Dapat Diaplikasikan Pada Daerah Kurang Air, Suhu Air Lebih Stabil, Ikan Tidak Berbau Tanah, Panen Ikan Lebih Mudah, Pengolahan Bak Lebih Cepat, Padat Tebar Benih Ikan Lebih Tinggi, Kotoran ikan dan sisa pakan yang menumpuk di dasar bak lebih mudah dibersihkan, ikan lebih sehat dan Jarang Ditemui Hama dan Penyakit, Kelangsungan Hidup Ikan Lebih Tinggi. Beberapa kekuarangan bak terpal yaitu Rawan bocor, Mudah lapuk karena hujan, Tidak awet, Miskin ion-ion dan mineral dari tanah, air kolam lebih cepat bau (Sumber : https://blog.agromaret.com/2018/04/kelebihan-dankekurangan-budidaya-di-kolam-terpal). Jika memper-timbangkan masalah biaya, mobilitas, dan kemudahan pengembangan, maka bak terpal adalah pilihan terbaik.

Desa Talabiu merupakan salah satu desa yang masuk adminitratif Kecamatan Woha Kabupaten Bima, Nusa Tenggara Barat. Dan merupakan salah satu desa pesisir teluk Bima yang banyak menghasilkan ikan Bandeng sebagai salah satu komoditi unggulan Kabupaten Bima. Pemanfaatan bak terpal untuk kegiatan budidaya perikanan baik untuk budidaya komoditi ikan air tawar, payau dan laut masih belum ada. Kegiatan ini diharapkan dapat menambah wawasan masyarakat tentang penggunaan bak terpal untuk wadah budidaya. Kegiatan ini merupakan kegiatan lanjutan dari program pengabdian kepada masyarakat yaitu tentang Pelatihan Pemeliharaan Larva Ikan Bandeng (Chanos chanos F.) Skala Rumah Tangga yang telah dijalankan tahin 2020 oleh tim pengabdian dari Program Vokasi Bima UNRAM. Dalam kegiatan tersebut diperoleh informasi bahwa salah satu kendala yang sedang dihadapi oleh masyarakat sasaran adalah keterbatasan wadah/bak untuk pemeliharaan ikan. Oleh karena itu, program pelatihan teknik pembuatan bak terpal yang akan dilakukan diharapkan mampu membuka pikiran dan meningkatkan keahlian masyarakat sasaran untuk mengembangkan sarana budidaya khususnya bak terpal secara mandiri dan berkelanjutan. Dengan kegiatan ini diharapkan akan muncul kegiatan budidaya komoditi ikan air tawar, air payau bahkan air laut sebagai sumber mata pencaharian alternatif di masa pandemi Covid-19 yang sedang mengalami pandemi saat-saat ini.

Kegiatan ini akan melibatkan semua mahasiswa Program Studi Budidaya Perairan Program Vokasi Bima UNRAM, Tenaga Penyuluh Perikanan Kabupaten Bima, kelompok masyarakat perikanan desa Talabiu Kabupaten Bima dan Pemerintah Daerah Kabupaten Bima.

\section{Metode}

Kegiatan pengabdian kepada masyarakat dilakukan dengan metode pelatihan. Implementasi kegiatan pengabdian dilakukan dengan tahapan sebagai berikut :

1) Identifikasi kondisi dan ketersediaan sarana dan prasarana pendukung pelatihan. Kegiatan ini dilakukan dengan cara menurunkan tim pengabdian untuk mendata sarana peralatan yang ada di 
lokasi pelatihan kemudian hasil pendataan ini dijadikan pertimbangan untuk menentukan langkah-langkah dalam kegiatan pengabdian kepada masyarakat;

2) Melakukan koordinasi secara informal dengan Ketua kelompok masayrakat sasaran sebagai langkah sosialisasi awal;

3) Melakukan Fokus Group Discussion (FGD) terkait dengan rencana pelaksanaan kegiatan;

4) Mengadakan pelatihan dengan tahapan kegiatan meliputi :

a. Persiapan lahan tempat pembuatan bak terpal;

b. Persiapan dan pengenalan alat dan bahan pembuatan bak terpal;

c. Instalasi unit-unit bak terpal;

d. Pengujian fungsi bak terpal.

\section{Hasil dan Pembahasan}

\section{a. Penyampaian Materi dan Diskusi}

Kegiatan pelatihan pembuatan bak terpal telah dilakukan pada tanggal 4 November 2021. Kegiatan ini dilaksanakan di halaman belakang rumah (back yard) Ketua Koperasi Produksi "Sama Ngawa Karawi” yang beralamat di Jl. Lintas Bima-Sumbawa RT 07/04 Desa Talabiu Kec. Woha, Kabupaten Bima. Kegiatan ini diawali dengan penyampaian materi dan diskusi. Materi yang disampaikan yaitu informasi mengenai pengunan bak terpal dalam budidaya perikanan, kelebihan bak terpal dan teknik pembuatan bak terpal. Penyampaian materi dilakukan dengan metode presentasi lewat projector yang dilaksanakan pada tuang pertemuan di halaman rumah kediaman Ketua Koperasi. Peserta yang diaundang adalah beberapa angota koperasi "Sama Ngawa Karawi”, tokoh masyarakat, beberapa masyarakat pembudidaya ikan dan seluruh mahasiswa Program Studi Budidaya Perairan Program Vokasi Universitas Mataram yang berlokasi di Kabupaten Bima. Kegiatan ini dihadiri oleh 36 orang (Gambar 1).

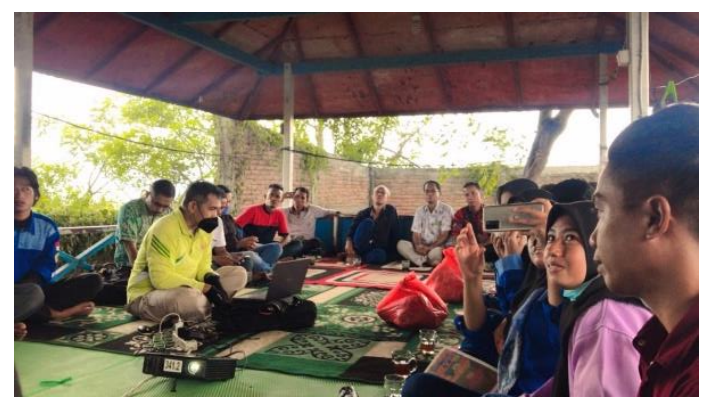

Gambar 1. Penyampaian materi dan diskusi bersama masyarakat sasaran.

\section{b. Praktek Pembuatan Bak Terpal}

Praktek pembuatan bak terpal di lapangan sangat dibutuhkan untuk meningkatkan pemahaman dan keterampilan masyarakat yang terlibat pada kegiatan yang dimaksud. Kegiatan ini dilakukan melalui tahapan-tahapan yaitu : 1) Pengenalan alat dan bahan; 2) Persiapan lokasi; 3) Persiapan saluran air dan pemipan; 4) Instalasi unit bak terpal; dan 5) Uji fungsi bak terpal.

1) Pengenalan alat dan bahan serta instalasi unit-unit wadah budidaya

Sebelum dilakukan pelatihan, terlebih dahulu dilakukan pengenalan alat bahan-bahan yang dibutuhkan seperti wire mesh, terpal, pipa saluran air, pasir, bata merah dan semen (Gambar 2). 

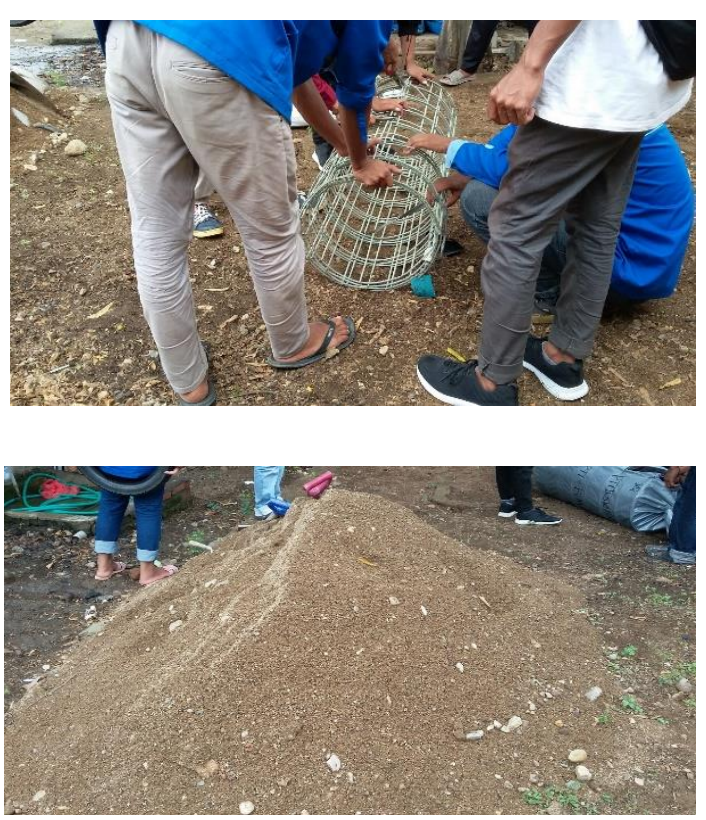

Gambar 2. Kegiatan pengenalan alat dan bahan-bahan yang akan digunakan. Wire mesh sebagai rangka bak terpal (kiri) dan pasir sebagai bahan untuk meratakan tanah dasar (kanan)

\section{2) Instalasi unit-unit bak terpal}

Kegiatan lanjutan dari pengenalan alat dan bahan yakni instalasi unit bak terpal. Kegiatan ini diawali dengan penetapan titik tempat peletakan bak terpal. Lokasi dibersihkan kemudian permukan tanah diratakan dengan menambahkan pasir. Bata merah digunakan sebagai penahan bagian luar dari bak terpal yang akan dibangun. Bata merah disusun melingkar mengikuti sisi luar lingkaran wire mesh yang menjadi rangka bagi bak terpal. Bata merah kemudian diperkuat dengan menambahkan adonan pasir campur semen. Setelah pembuatan penahan bak terpal selesai dibuat, selanjutnya dilakukan instalasi pipa saluran pembuangan berupa pipa paralon dengan diameter 1,5 inci. Pipa saluran air dibuat dengan kemiringan 5\% mengarah ke saluran pembuangan (selokan). Rangka bak terpal yaitu wire mesh diletakan pada posisi yang direncanakan kemudian dilanjutkan dengan pemasangan terpal pelindung dan terpal utama. Akhir dari kegiatan ini adalah uji fungsi bak dengan mengisi air ke dalam bak terpal yang telah dibuat kemudian kebocoran bak diamati selama 10-15 menit. Jika ditemukan adanya kebocoran maka dilakukan perbaikan. Hasil pengamatan menunjukkan bahwa bak terpal yang dibangun dapat berfungsi normal tanpa memperlihatkan tanda-tanda adanya kebocoran. Keseluruhan rangkaian kegiatan instalasi unit-unit bak terpal ditampilkan pada Gambar 3 dan Gambar 4.

Kegiatan pelatihan ini dilakukan dengan dua tahapan umum yaitu diskusi dan praktek lapangan. Untuk memperlancar diskusi dilakukan presentasi melalui media slide power point yang dikombinasikan dengan penyampaian vidio tentang tutorial pembuatan bak terpal yang diakses pada link https://www.youtube.com/watch?v=OM 2fK8az410. Materi yang disampaikan terlihat cukup dipahami oleh peserta dan tidak banyak pertanyan yang disampaikan saat diskusi dilakukan. Dalam kegiatan diskusi ini beberapa hal umum telah ditanyakan oleh peserta diantaranya bagaimana melakukan budidaya kepiting bakau yang saat ini populasinya di Kabupaten Bima mengalami penurunan, bagaimana meningkatkan kualitas ikan bandeng yang dirasakan berbeda dibandingkan dengan beberapa tahun yang lalu. Hal-hal umum terkait dengan pertanyaan peserta pelatihan juga telah dijelaskan dan menjadi materi tambahan saat 
diskusi dilakukan. Peserta pelatihan sangat mengharapkan adanya pelatihan-pelatihan berikutnya yang diselengarakan oleh Program Vokasi

Universitas Mataram di Kabupaten Bima.
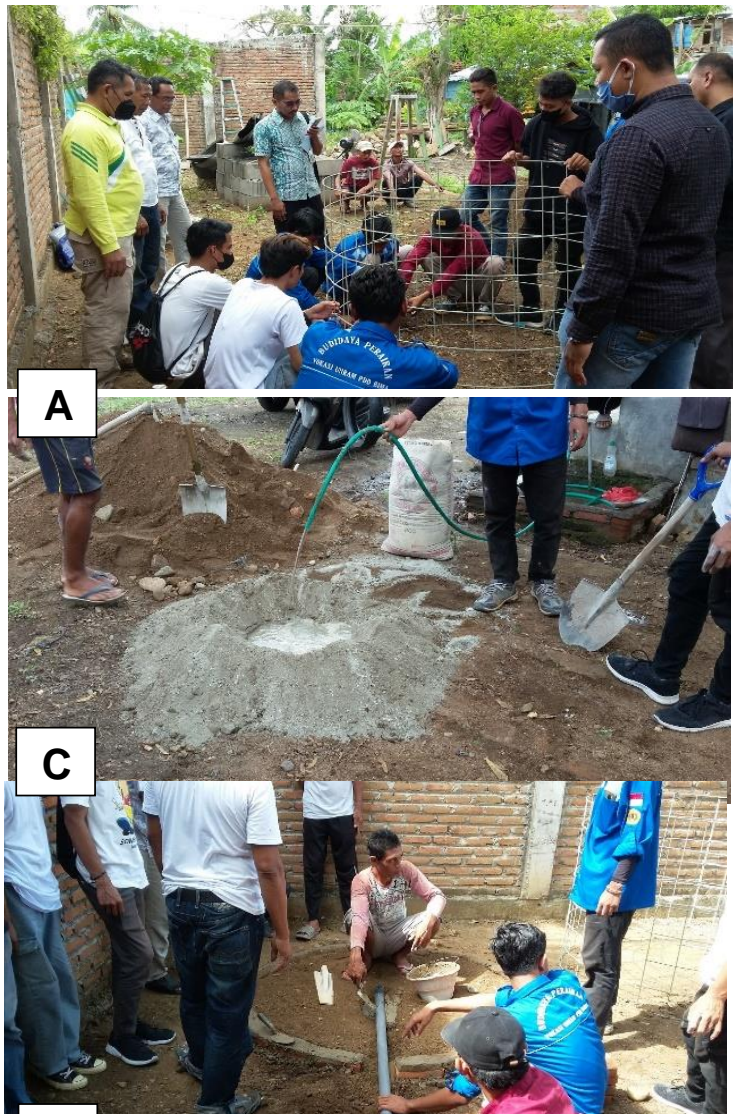

E

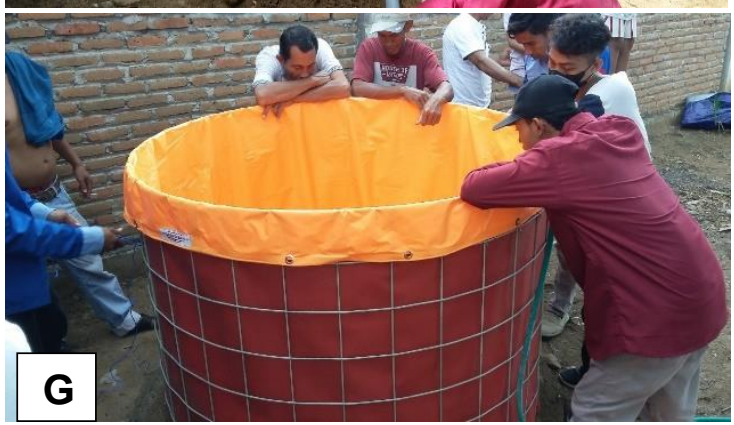

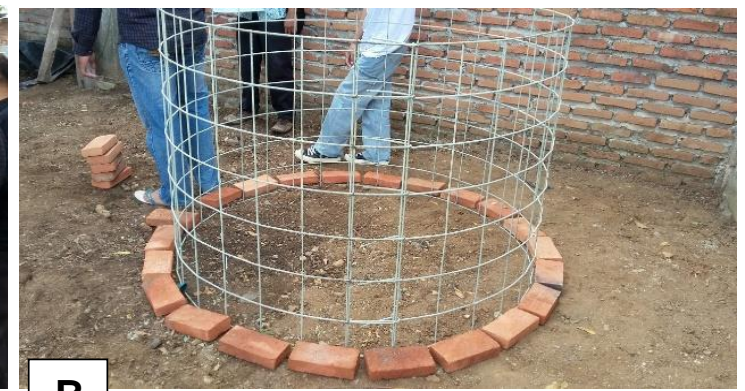

B
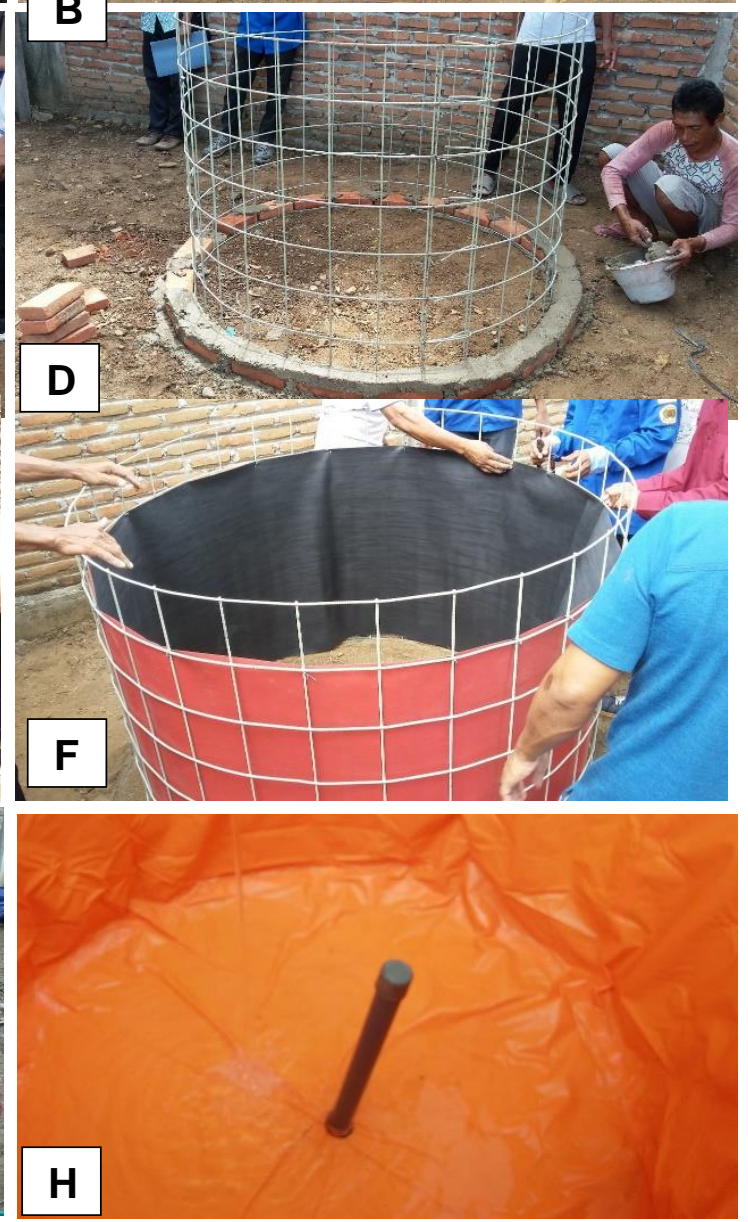

Gambar 3. Instalasi unit-unit bak terpal. Keterangan : $\mathrm{A}=$ Perakitan wire mesh sesuai ukuran diameter bak; $\mathrm{B}=$ Penempatan posisi rangka besi pada lokasi yang ditentukan; $\mathrm{C}=$ Persiapan adonan semen/pasir; $\mathrm{D}=$ Pemasangan bata penahan bak terpal; $\mathrm{E}=$ Pemasangan pipa saluran air; $F=$ Pemasangan terpal pelapis; $G=$ Pemasangan terpal utama; $\mathrm{H}=$ Pemasangan pipa penutup saluran air. 

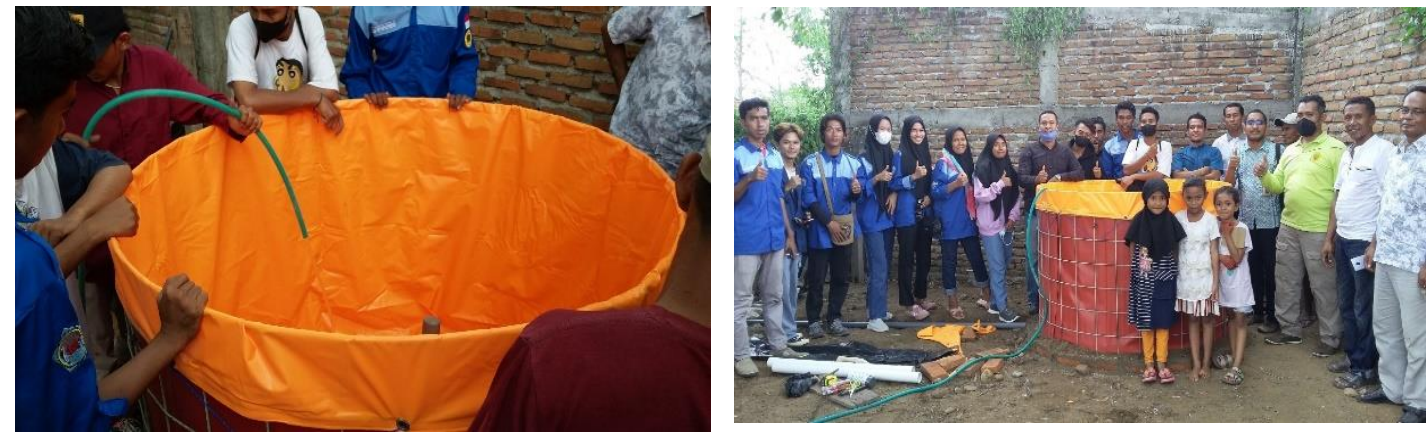

Gambar 4. Pengisian air ke dalam wadah budidaya untuk mengevaluasi permasalahan kebocoran bak terpal sebelum digunakan oleh masyarakat (mitra). Pengisian air ke dalam bak (kiri) dan foto bersama dengan peserta pelatihan (kanan).

Selain masyarakat umum, pelatihan ini juga melibatkan seluruh mahasiswa Program Studi Budidaya Perairan Program Vokasi Universitas Mataram yang berlokasi di Kabupaten Bima. Kegiatan ini juga dimaksudkan untuk meningkatkan pemahaman dan keterampilan mahasiswa yang terlibat dalam mempersiapkan wadah budidaya untuk budidaya komoditi perairan laut, perairan payau dan budidaya perairan tawar. Kegiatan yang dilakukan terlihat direspon baik oleh peserta. Hal ini dapat dilihat dari keaktifan dan ikut terlibatnya mereka dalam seluruh rangkaian kegiatan pelatihan. Kegiatan pelatihan ini diharapakan dapat merangsang masyarakat untuk melakukan budidaya ikan yang berkelanjutan. Kegiatan ini telah ditindaklanjuti oleh Mitra yang terlibat dengan menambah jumlah bak terpal untuk pemeliharan ikan Lele dan Ikan Nila.

\section{Kesimpulan}

Kegiatan pelatihan pembuatan bak terpal telah dilakukan pada tanggal 4 November 2021 berlokasi di Desa Talabiu Kecamatan Woha Kabupaten Bima dihadiri oleh peserta sebanyak 36 orang berasal dari anggota koperasi produsen Sama Ngawa Karawi, masyarakat pembudidaya ikan, tokoh masyarakat sekitar, dan mahsiswa Program Studi Budidaya Perairan Program Diploma Tiga Program Vokasi Universitas Mataram di
Kabupaten Bima. Tahapan pelatihan dimulai dari diskusi, instalasi unit-unit bak terpal dan uji fungsi unit bak terpal. Seluruh peserta yang hadir telah menunjukkan respon yang positif dan mengikuti kegiatan pelatihan mulai dari awal hinga akhir.

Kegiatan berikutnya yang perlu dilakukan yaitu pendampingan pada tahapan budidaya perikanan bagi masyarakat, pendampingan kegiatan produksi pakan yang murah dan efektif untuk kebutuhan mitra, peningkatan pemahaman tentang pasca panen untuk meningkatkan kualitas produk, dan kegiatan pendampingan pada pemasaran.

\section{Daftar Pustaka}

Ayuzar, E. dan Zuriani. 2017. IBIKK Budidaya Ikan Patin (Pangasius sp.) di Kolam Terpal. Dharma Raflesia Unib. Tahun XV, Nomor $2: 81-88$

Irsyam, M., I. Nuryadin, S.R. Drajat, D.S. Ramadhan dan Sahabuddin. 2019. Analisa Usaha Budidaya Udang Vaname (Litopenaeus vannamei) pada Kolam Terpal Bundar dengan Sistem Microbuble. Prosiding Simposium Nasional Kelautan dan Perikanan VI. Universitas Hasanuddin, Makassar : 201-206.

Lisanty, N., S. Bayu dan A.D. Pamujiati. 2020. Budidaya perikanan skala kecil: studi kasus ternak ikan gurami (Osphronemus gouramy) di Desa Mojosari Kecamatan 
Kras Kabupaten Kediri. Jurnal AGRINIKA. Volume 4, No. 1: 1-43.

Mas'ud, F. dan T. Wahyudi. 2018. Analisa usaha budidaya udang vaname (Litopenaeus vannamei) air tawar di kolam bundar dengan sistem resirkulasi air. Jurnal Sumberdaya Akuatik Indopasifik. Vol. 2 No. 2 : 103-108

Rundupadang, S.S. 2020. Efektifitas umpan hidup bandeng (Chanos chanos Forskal) hasil budidaya dan umpan hidup dari alam pada perikanan pole and line. Tesis. Program Studi Magister Ilmu Perikanan Fakultas Ilmu Kelautan Dan Perikanan Universitas Hasanuddin. Makassar : $42 \mathrm{hlm}$.

Sari, I.P., Yulisman dan Muslim. 2017. Laju pertumbuhan dan efisiensi pakan ikan nila (Oreochromis niloticus) yang dipelihara dalam kolam terpal yang dipuasakan secara periodik. Jurnal Akuakultur Rawa Indonesia. Volume 5, No. $1: 45-55$

Sukardi, P., P.H.T Soedibya, T.B. Pramono. 2018. PRODUKSI budidaya ikan nila (Oreochromis niloticus) sistem Bioflok dengan sumber karbohidrat berbeda. AJIE Asian Journal of Innovation and Entrepreneurship. Volume 03, Issue : 02 : 198-203.

Su'udi, M dan S. Wathon. 2018. Peningkatan Performa Budidaya Lele Dumbo (Clarias gariepinus, Burch) Di Desa Serut Kecamatan Panti Kabupaten Jember Provinsi Jawa Timur. Warta Pengabdian. Volume 12, Issue $2:$ 298-306. 